\author{
К. А. Посохова, О. М. Олещук, О. О. Шевчук
}

ДВНЗ “Тернопільський державний медичний університет імені І. Я. Горбачевського МОЗ України”

\title{
ВИСВІТЛЕННЯ ПРОБЛЕМ РАЦІОНАЛЬНОГО ЗАСТОСУВАННЯ АНТИБІОТИКІВ ПРИ ВИКЛАДАННІ ФАРМАКОЛОГІЇ
}

\author{
K. A. Posokhova, O. M. Oleshchuk, O. O. Shevchuk \\ I. Horbachevsky Ternopil State Medical University

\section{PROBLEMS OF THE RATIONAL ADMINISTRATION OF ANTIBIOTICS IN PHARMACOLOGY TEACHING}

\begin{abstract}
Мета роботи - аналіз проблем раціонального застосування антибіотиків та шляхів їх вирішення при викладанні фармакології. Основна частина. Проаналізовано основні проблеми, які перешкоджають ефективній антибіотикотерапії у наш час (прогресуюче зростання резистентності мікроорганізмів, нераціональне, надмірне застосування антибіотиків у клінічній практиці) та підкреслено важливість подачі цього матеріалу студентам для усвідомлення ними належних правил використання антибіотиків.

Висновок. Аналіз причин антибіотикорезистентності, проблем раціонального призначення антибактеріальних препаратів та шляхів їх вирішення при викладанні теми “Фармакологія антибіотиків” є важливою складовою ефективного опанування студентами цього важливого матеріалу з метою використання у майбутній лікарській діяльності.
\end{abstract}

Ключові слова: фармакологія; антибіотики; раціональне застосування.

The aim of the work - analysis of problems of antibiotics rational use and the ways of their solution in the teaching of pharmacology.

The main body. The current main problems that impede effective antibiotic therapy (progressive growth of microorganism resistance, irrational, excessive antibiotics use in clinical practice) are analyzed and it is emphasized on the importance of learning this information by the students for their awareness of the rules of antibiotic administration.

Conclusion. The analysis of the causes of antibiotic resistance, the problems of rational use of antibacterial drugs and the ways to solve them are an important component of effective students' mastering of the topic "Pharmacology of antibiotics" for use in future medical activities.

Key words: pharmacology; antibiotics; rational administration.

Вступ. Багаторічне викладання теми “Фармакологія антибіотиків” переконує в тому, що це одна з найважчих тем фармакології, ефективне опанування якої студентами потребує розгляду та аналізу ряду проблем із метою їх обов'язкового подальшого врахування та ефективного вирішення у клінічній практиці. До глобальних проблем, які існують у сфері застосування антибіотиків (АБ), належать прогресуюче наростання резистентності збудників інфекційних процесів до цих засобів та нераціональне їх використання. Ці явища нерозривно зв'язані одне з одним.

Мета роботи - аналіз проблем раціонального застосування антибіотиків та шляхів їх вирішення при викладанні фармакології.

Основна частина. Відтоді як у 40-ві роки минулого століття у клінічну практику був впроваджений перший АБ, відбувалося неухильне зростання резистентності мікроорганізмів до існуючих засобів цього ряду, яка на сьогодні перетворилася на фактор, який, за визначенням ВООЗ, створює реальну загрозу для існування людської цивілізації [1]. У багатьох випадках лікарі стикаються із ситуаціями, коли призначення найпотужніших АБ не дає бажаного ефекту. Це призводить до різкого зростання рівня захворюваності, тяжкості перебігу, частоти летальних наслідків при бактеріальних інфекційних процесах. Якщо на сьогодні щорічна смертність від захворювань, спричинених резистентними формами мікроорганізмів, у всьому світі становить 700000 випадків, то до 2050 року ця цифра зросте до 50000 000. До збудників, які резистентні до існуючих АБ і які отримали назву “super bugs” чи “еscape-патогени”, насамперед належать Enterococcus faecium, Staphylococcus aureus, Klebsiella pneumoniae, Acinetobacter baumannii, Pseudomonas aeruginosa, представники родини Enterobacteriaceae.

\footnotetext{
(c) К. А. Посохова, О. М. Олещук, О. О. Шевчук
} 
До медичних причин, що призводять до стрімкого зростання антибіотикорезистентності, належать:

- зловживання призначенням АБ, у тому числі 3 метою самолікування;

- недостатнє використання мікробіологічних досліджень для точного визначення етіологічного чинника та його чутливості до АБ;

- використання нових АБ, часто - широкого спектра дії, у випадках доведеної ефективності засобів з вужчим спектром;

- недотримання пацієнтами визначених режимів прийому АБ;

- нераціональне профілактичне застосування АБ лікарями хірургічних спеціальностей;

- переповнення і недостатній санітарний режим у лікарнях;

- імуносупресивні стани.

Зокрема, доведено, що понад 50 \% всіх АБ, які призначають в амбулаторних умовах при ГРВІ (гострому риніті, синуситі, трахеобронхіті), не потрібні, виходячи з того, що жоден з існуючих антибактеріальних АБ на віруси не діє.

Недопустиме також зловживання АБ для профілактики бактеріальних ускладнень після оперативних утручань. Надзвичайно серйозною проблемою хірургічних стаціонарів сьогодні є розповсюдження внутрішньолікарняних мікроорганізмів, які формують біоплівки, що є своєрідним захистом від впливу факторів зовнішнього середовища, способом персистенції мікроорганізмів в організмі хворого та на навколишніх об’єктах, у тому числі на ендоскопах, катетерах, протезах тощо. Часто це унеможливлює ефективне лікування нозокоміальних інфекцій, тому що ступінь стійкості мікроорганізмів у біоплівці до дії дезінфекційних засобів та антибіотиків у 100-1000 разів вищий від планктонних форм [2]. Необхідно наголошувати на тому, що для протидії цьому явищу, ефективного попередження інфекційних ускладнень і подальшого стрімкого зростання резистентності мікроорганізмів хірургічну профілактику слід проводити лише у випадках і лише тими АБ, які визначено у відповідному наказі MO3 [3].

Майбутні лікарі також повинні бути обізнані в інших важливих причинах зростання антибіотикорезистентності. Зокрема, суттєвий внесок у це явище робить широке використання АБ у сільському господарстві, тваринництві, птахівництві як засобів профілактики та лікування захворювань тварин і рослин та стимуляторів росту [4]. Відомо, що лише половина тих АБ, які виробляються у світі, використовується для людей. У побуті АБ входять до складу харчових продуктів, напоїв, косметики, засобів гігієни.

У цих складних умовах дуже важливим є максимально раціонально підходити до призначення АБ, що, у свою чергу, потребує від лікаря глибоких знань не лише їх властивостей, які представлені у літературі та інструкціях до застосування, але насамперед об’єктивного оцінювання конкретного випадку інфекційного процесу та вибору найефективнішого АБ для його лікування.

Для раціонального призначення АБ слід спершу встановити, використовуючи літературні джерела, які збудники найбільш імовірно викликають дане захворювання. Наступний етап - вибір певної групи АБ, виходячи з особливостей їх природного антибактеріального спектра. Водночас слід наголошувати на тому, що відомості про активність будь-якої групи АБ, які були зареєстровані на момент її впровадження у клінічну практику, сьогодні можуть суттєво відрізнятися від реального стану речей, що зумовлено високим рівнем розвитку резистентності мікроорганізмів до АБ. Тому слід орієнтуватись на інформацію, яка представлена у найсучасніших клінічних протоколах, у наукових статтях, матеріалах конгресів, конференцій, присвячених цьому питанню, у спеціальних довідниках $[5,6]$, що регулярно перевидаються, тож містять найбільш об’єктивні дані. Постійне ознайомлення 3 новою інформацією у цій сфері $є$ надзвичайно важливим для лікарів будь-якого фаху протягом їх практичної діяльності.

Незважаючи на те, що золотим стандартом визначення чутливості мікробів до АБ залишається мікробіологічний аналіз, терміни якого останнім часом істотно скоротились, його з об’ єктивних причин не завжди вдається провести. Це підтверджує необхідність тверезого оцінювання конкретної ситуації та вибору АБ, який може бути найбільш ефективним при цьому. Нерідко, з огляду на зазначене вище та у невідкладних випадках, необхідно вдаватися до емпіричного призначення АБ. При цьому раціонально використовувати не лише спостереження за рівнем резистентності збудників у даному лікувальному закладі, але й відомості, представлені у спеціальній літературі [5].

Все це переконує у недопустимості самолікування АБ, рутинного призначення лікарями АБ широкого спектра дії (за принципом “а може, буде ефект”) там, де можна обійтись ефективним засобом з вузьким антибактеріальним спектром. 
Призначаючи будь-який АБ, особливо в амбулаторній практиці, лікар повинен переконатись, що пацієнт буде строго виконувати його рекомендації, з огляду на те, що дострокове припинення прийому АБ або порушення кратності його використання може негативно вплинути на результати антибіотикотерапії і супроводжуватися подальшим зростанням резистентності мікроорганізмів. На жаль, відповідно до світових даних, 20-50 \% пацієнтів не приймають АБ згідно з призначенням лікаря.

Інколи зменшення або відсутність антибактеріальної дії деяких АБ зв’язані з ігноруванням результатів їх взаємодії з іншими лікарськими засобами або ж з продуктами харчування [7]. Зокрема, загальновідомо, що прийом фторхінолонів, тетрациклінів не можна проводити з препаратами, які містять іони заліза (засоби для лікування анемії), кальцію, магнію, алюмінію (антацидні препарати), оскільки може різко зменшитися біодоступність АБ і, відповідно, ефективність антибіотикотерапії.

Слід також орієнтувати студентів на те, що серед усіх груп лікарських препаратів, які використовуються в Україні, найчастіше побічні реакції і ускладнення викликають саме АБ - майже 64 \% від усіх випадків, що реєструються $[8,9]$. Дуже часто це алергічні прояви, аж до розвитку анафілактичного шоку. Майбутні лікарі повинні бути обізнані про високу ймовірність виникнення перехресної алергії при застосуванні АБ з подібною будовою. Зокрема, якщо у пацієнта в анамнезі реєструвалась алергічна реакція на будь-який препарат із групи біосинтетичних пеніцилінів, висока ймовірність виникнення тяжких алергічних проявів при застосуванні інших бета-лактамних АБ, особливо

\section{Список літератури}

1. Резистентність мікроорганізмів до антибіотиків як екстремальний фактор впливу на людину / К. А. Посохова, О. М. Олещук, О. О. Шевчук, А. С. Вольська // Актуальні питання патології за умов дії надзвичайних факторів на організм : матеріали XI наук.-практ. конф. 3 міжнар. участю (Тернопіль, 4-5 жовтня 2018 р.). - Тернопіль, 2018. - С. 29-30.

2. До питання про чутливість: стійкість біоплівок сальмонел до дії дезінфектантів / В. Ф. Марієвський, В. О. Бубало, Н. М. Кролевецька [та ін.] // Запорожский мед. журнал. - 2013. - № 5 (80). - С. 80-83.

3. Про організацію контролю та профілактики післяопераційних гнійно-запальних інфекцій, спричинених мікроорганізмами, резистентними до дії антимікробних препаратів : наказ МОЗ України від 04.04.2012 р. № 236 . напівсинтетичних пеніцилінів, у тому числі інгібітор-захищених, цефалоспоринів 1-2 генерації та тієнаміцинів.

Для сповільнення розвитку резистентності мікроорганізмів до АБ та раціоналізації їх використання ВООЗ міжнародні та національні структури, які займаються цими проблемами, пропонують такі заходи:

- мікробіологічний моніторинг чутливості мікроорганізмів до АБ (локальний, регіональний) з метою цілеспрямованого впливу на них та покращання результатів лікування;

- обмеження застосування АБ лікарями (призначення при найбільш серйозних ситуаціях);

- попередження самолікування, строго рецептурний відпуск АБ в аптеках;

- широке використання освітніх програм для лікарів та провізорів з питань застосування АБ;

- встановлення жорстких гігієнічних заходів, особливо в лікарнях;

- обмеження і заборона застосування АБ у сільському господарстві, ветеринарії, харчовій промисловості, побутових продуктах;

- створення нових АБ.

Висновки. 1. Найважливішими проблемами, 3 якими стикається людство у XXI столітті при лікуванні інфекційних процесів, $є$ стрімке наростання резистентності мікроорганізмів до всіх існуючих антибіотиків та нераціональне застосування цих засобів.

2. Важливою складовою ефективного опанування студентами теми “Фармакологія антибіотиків” $\epsilon$ аналіз причин антибіотикорезистентності, проблем раціонального призначення антибактеріальних препаратів та шляхів їх вирішення.

4. A review of antibiotic use in food animals: perspective, policy, and potential / T. F. Landers, B. Cohen, T. E. Wittum [et al.] // Public Health Rep. - 2012. - Vol. 127 (1). - P. 4-22.

5. Березняков И. Г. Краткий справочник по эмпирическому использованию антибиотиков с лечебной и профилактической целью / И. Г. Березняков. - 2-е изд., дополн. и перераб. - К. : Вид. ТОВ “НПВ “Інтерсервіс”, 2018. - 223 c.

6. The Sanford guide to antimicrobial therapy (2016), 46th Ed. / D. N. Gilbert, H. F. Chambers, G. M. Eliopoulos [et al.]. - Publisher Antimicrobial Therapy, Inc. - P. 261.

7. Посохова К. А. Вплив індивідуальних особливостей організму, патологічних процесів, комбінованого застосування лікарських засобів на їх ефективність / К. А. Посохова, О. В. Матвєєва // Укр. мед. часопис. 2018. - T. 2, № 4 (126). - С. 14-18. 
8. Посохова К. А. Фармаконагляд у закладах охорони здоров’я Тернопільської області у 2017 році / К. А. Посохова, Л. М. Матюк // Раціональна фармакотерапія. 2018. - № 2 (47). - С. 51-53.

9. Посохова К. А. Побічні реакції антибактеріальних препаратів у закладах охорони здоров’я Тернопільської

\section{References}

1. Posokhova, K.A., Oleshchuk, O.M., Shevchuk, O.O., \& Volska, A.S. (2018). Rezystentnist mikroorhanizmiv do antybiotykiv yak ekstremalnyi faktor vplyvu na liudynu [Resistance of microbes to antibiotics as an extremal impact to the human]. Materialy XI nauk.-pr. konf. “Aktualni pytannia patolohii za umov dii nadzvychainykh faktoriv na orhanizm - Paper presented at the XI-th Conference "Actual Problems of Pathology under the Influence of Extreme Factors to the Human”. (pp. 29-30). Ternopil: Ukrmedknyha [in Ukrainian].

2. Mariievskyi, V.F., Bubalo, V.O., Krolevetska, N.M., Ruban, N.M., Diachenko, O.P., \& Matoshko, H.V. (2013). Do pytannia pro chutlyvist: stiikist bioplivok salmonel do dii dezinfektantiv [About sensitivity: Salmonella biofilms resistance against disinfectants]. Zaporozhskyy medytsynskyy zhurnal - Zaporozhye Medical Journal, 5 (80), 80-83 [in Ukrainian].

3. Nakaz MOZ Ukrainy vid 04.04.2012 № 236 “Pro orhanizatsiiu kontroliu ta profilaktyky pisliaoperatsiinykh hniino-zapalnykh infektsii, sprychynenykh mikroorhanizmamy, rezystentnymy do dii antymikrobnykh preparativ" [Order of the Ministry of Health of Ukraine of 04.04.2012 No. 236 "On the organization of control and prevention of postoperative purulent inflammatory infections caused by microorganisms resistant to the action of antimicrobial drugs"]. [in Ukrainian].

4. Landers, T.F., Cohen, B., Wittum, T.E., \& Larson, E.L. (2012). A review of antibiotic use in food animals: perspective, policy, and potential. Public Health Reports, 127 (1), 4-22. області у 2017 році / К. А. Посохова, Л. М. Матюк // Жіноче здоров’я: імплементація сучасних протоколів в клінічну практику : зб наук. праць Всеукр. міждисципл. наук.-практ. конф., 1-2 березня 2018 року / за ред. М. М. Корди, М. І. Шведа, С. М. Геряк. - Тернопіль : Підручники і посібники, 2018. - С.113.

5. Bereznyakov, I.G. (2018). Kratkiy spravochnik po empiricheskomu ispolzovaniyu antibiotikov s lechebnoy $i$ profilakticheskoy tselyu [Brief guide for empiric uses of antibiotics for treatment and prophylaxis]. Kyiv: NPV "Interservis" [in Russian].

6. Gilbert, D.N., Chambers, H.F., Eliopoulos, G.M., Saag, M.S., \& Pavia, A.T. (2016). The Sanford Guide to antimicrobial chemotherapy. Publisher Antimicrobial therapy.

7. Posokhova, K.A., \& Matveieva, O.V. (2018). Vplyv indyvidualnykh osoblyvostei orhanizmu, patolohichnykh protsesiv, kombinovanoho zastosuvannia likarskykh zasobiv na yikh efektyvnist [Influence of personal features, pathological processes and combined administration of medicines on their efficacy]. Ukr. med. Chasopys - Ukrainian Medical Herald, 4 (2) 126, 14-18 [in Ukrainian].

8. Posokhova, K.A., \& Matiuk, L.M. (2017). Farmakonahlyiad u zakladakh okhorony zdorovia Ternopilskoi oblasti u 2017 rotsi [Pharmacovigilance in health care institutions of Ternopil region in 2017]. Ratsionalna farmakoterapiia Rational Pharmacotherapy, 2 (47), 51-53 [in Ukrainian].

9. Posokhova, K.A., \& Matiuk, L.M. (2018). Pobichni reaktsii antybakterialnykh preparativ u zakladakh okhorony zdorovia Ternopilskoi oblasti u 2017 rotsi [Side effects of antibacterial medicines in health care institutions of Ternopil region in 2017]. Korda, M., Shved, M., \& Heriak, S. (Eds.). Zhinoche zdorovia: implementatsiia suchasnykh protokoliv $v$ klinichnu praktyku - Woman health: implementation of modern protocols into clinics. Ternopil: Pidruchnyky i posibnyky [in Ukrainian]. 